\title{
Determinants of environmental disclosures of listed firms in Ghana
}

\author{
Emerald Edem Welbeck, Godfred Matthew Yaw Owusu*, Rita Amoah Bekoe and John Amoah Kusi
}

\begin{abstract}
The purpose of the paper is to examine the type of environmental-related information firms disclose mostly in Ghana, the trend of such disclosures and investigate the determinants of environmental disclosures by firms in Ghana. Using the Global Reporting Initiative (GRI) index as a benchmark, a content analysis of the corporate annual report of 17 firms listed on the Ghana Stock Exchange (GSE) was conducted over a 10-year period (2003 to 2012) to determine the total environmental disclosure scores of the sampled firms. The determinants of environmental disclosure practices of the firms were ascertained by means of a regression analysis. Results of this study indicate that listed firms in Ghana disclose some amount of environmentally-related information espoused by GRI though the level of disclosure is low. Also, the level of disclosure by environmentally-sensitive firms is higher than the less sensitive firms similar to existing studies. Moreover, the study finds firm size, auditor type, age of the firm and industry type to be significant predictors of firms' environmental disclosure practices.
\end{abstract}

\section{Background}

The relationship between business organizations and their environment in contemporary times has witnessed drastic changes. Until recently, environmental and social issues were not seriously considered in management objectives because they were deemed not to have any significant financial impact (Pereira Eugénio et al. 2013). But in a bid to gain legitimacy, most organisations have recognized the relevance of their environment to their businesses and the need to safeguard it. As Díez-Martín et al. (2013) maintain, a number of organizations have failed not because they lack resources or because of faulty products, but due to a complete loss or deterioration of their legitimacy. Consequently, research on environmental disclosures has gained prominence in recent times. The growth in research focus on environmental disclosure issues has been borne out of the growing concern over the harmful effect of business activities on the environment.

In particular, major stakeholders have expressed concern in diverse ways over how the environment could be preserved for the generations to come (Gray et al. 2001; Jenkins and Yakovleva 2006). The environmental

\footnotetext{
* Correspondence: gmowusu@gmail.com; gmyowusu@ug.edu.gh Department of Accounting, University of Ghana Business School, Legon, Accra, Ghana
}

and social implications of the economic activities of businesses have therefore heightened the demands on organisations for information on their sustainability behaviour (Ingley 2008). In response to these demands, attempts have been made by some managers of companies to account for their actions and inactions on the environment in a way to assure stakeholders of their willingness and preparedness to safeguard the environment in which they operate. Indeed, it is increasingly becoming a common practice to see companies go the extra mile to inform and explain the impact of some of their environmental activities and initiatives to major stakeholder groups (Wilmshurst and Frost 2000). While these actions may have direct cost implication to these organisations, the relevance of incorporating societal needs into an organisation's activities has been recognised to be crucial to the very existence and survival of the organisation (Deegan et al. 2002). As Chelli et al. (2014) posit, organisational glosurvival depends on its capacity to manage the demands of its environment, as it is the environment that holds the resources for its survival.

In the field of accounting, a number of studies have assessed environmental performance of firms usually by examining their environmental disclosure practices (Sumiani et al. 2007; Deegan et al. 2002; de Villiers and Barnard 2000; Tilling and Tilt 2010). Others have established the relationship between environmental 
information disclosed and firm characteristics (Nor et al. 2016; Cormier et al. 2005; Deegan et al. 2002). While the above studies suggest a considerable amount of research has been undertaken on environmental disclosure issues, findings of most of the studies have largely been based on views of employees usually by means of a cross-sectional survey (see Ahmad et al. 2003; Fifka 2012; Suttipun and Stanton 2012; Sulaimana et al. 2014; Chandok et al. 2017). In practice however, it is difficult to generalize conclusions drawn on the level of environmental disclosures by firms based on these studies and hence, there has been calls for longitudinal studies (Ahmad et al. 2003; Suttipun and Stanton 2012).

Moreover, most of these studies have also been restricted to the developed world and very few studies, to date, have examined the actual environmental reporting practices of firms within the context of developing countries, particularly Africa (Fifka 2012). With the exception of few notable studies from South Africa (de Villiers and Barnard 2000; de Villiers and Lubbe 2001; de Villiers 2003; Mitchell and Quinn 2005; Mitchell and Hill 2010), environmental disclosure studies have not received the needed research attention within the African continent despite the fact that a number of environmentally sensitive activities abound, being one of the most endowed continent with natural resources (including gold, bauxite, manganese, diamond, cotton etc.). This is however not surprising, given that research on many topical issues in general are still evolving within the African continent. Moreover, compared to developed countries, most developing countries have over the years placed less emphasis on environmental issues. Against the backdrop that environmental performance of most countries within the African continent are poor compared with the developed countries, ${ }^{1}$ the need for an assessment of the environmental reporting practices of firms in Africa cannot be overemphasized.

This study therefore aims at filling the above gaps in the literature by providing some evidence on environmental information that firms listed on the Ghana Stock Exchange disclose most. Unlike most existing studies that make use of cross-sectional data, the current study employs a longitudinal data to investigate the environmental practices of firms and the key predictors of firms' environmental disclosure practices. In achieving the study objectives, the Global Reporting Initiative Index (GRI) was used as a benchmark. The country Ghana, provides a good setting for a study of this nature as it is among the list of African countries with diverse natural resource endowment with the latest being the discovery of oil in commercial quantities.
The use of the GRI offers the researchers the opportunity to assess the disclosure practices of firms by international standards as there are no standards for content and structure of environmental report in Ghana. While prior studies have benchmarked environmental disclosure against ISO 14000 (Sumiani et al. 2007), the GRI is a globally accepted reporting framework aimed at enhancing the quality, rigor, and utility of sustainability reporting (Global Reporting Initiative 2002). The content analysis results indicate that listed firms in Ghana are disclosing some environmentalrelated information with a focus on product and service information compared to other environmental issues. The regression analysis also suggests firm size, industry type and age are key determinants of firms' environmental disclosure practices.

The remaining parts of the paper are organized as follows: the next section discusses theoretical and empirical reviews followed by research methodology; the empirical results and discussions are then presented followed by the concluding remarks.

\section{Theoretical review- legitimacy theory}

Companies exist and operate within the society. Hence, the importance of the immediate society (environment) within which organisations operate and the need to critically incorporate societal needs into their day to day activities is crucial. This is because organisations rely on the environment to guarantee access to the resources they need (Pfeffer and Salancik 1978). Thus, in order to acquire the resources, these organisations must constantly interact with their environment. Impliedly, the performance and survival of an organisation in part is dependent on the support it receives from its immediate environment (Díez-Martín et al. 2013; Chelli et al. 2014). Ingley (2008) posits that the social and environmental implications of a firm's economic activity have led to a significant increase in the demands placed on companies in relation to the sustainability of their behaviour and the information which they provide. Literature suggests that the idea behind corporate social and environmental reporting behaviour is to gain legitimacy or societal acceptance (Deegan et al. 2002; Mitchell et al., 2005; Tilling and Tilt 2010).

The legitimacy theory, built on the concept of organisational legitimacy, originated from the notion of a social contract. It has been described as the gap between societal expectation and that of the organization (Dowling and Pfeffer 1975). Whether expressed or implied, organizations operate in a society via a social contract where its survival and growth are based on the delivery of some socially desirable ends to the society in general and the distribution of economic, social or political benefits to the groups from which it derives its 
powers (Shocker and Sethi 1974). Based on this perceived contract, there is always a threat to the legitimacy of an organization when societal expectations of its behaviour differ from actual behaviour (Pereira Eugénio et al. 2013). Indeed, the society could revoke the organizations contract to continue its operations which could affect the future existence of the company (Deegan et al. 2002). Deegan (2002) further notes that it is the society that confers upon an organization the state of legitimacy since such companies do not have inherent right to resources.

Consequently organizations are under inherent pressure to demonstrate that society requires its services and that the group benefiting from its rewards have societal approval (Chelli et al. 2014). Empirical studies argue that companies engage in voluntary environmental disclosure practices to reduce this expectation gap and obtain favour with stakeholders or the society within which they operate (O'Donovan 2002; Lindblom 1994). It is on this basis that existing studies have usually employed the legitimacy theory to explain the environmental disclosure behaviour of corporate bodies (Wilmshurst and Frost 2000; O'Donovan 2002; Deegan et al. 2002; Branco and Rodrigues 2006; Brown and Deegan 1998). Similar to these studies therefore, this study argues that environmental disclosure practices of firms could be explained by the threat to their legitimacy by the immediate society. Accordingly, it is predicted that firms will disclose more on the environment where the threat to their legitimacy is high and disclose less when their legitimacy is not threatened in any way by the society. Given that the stock market in Ghana is not as vibrant as those from the developed world, coupled with the fact that stakeholder activism is not that strong to exert pressure on organisations to respond to societal needs, this study expects the level of environmental disclosure in Ghana to be relatively low.

The next section discusses firm specific characteristics that are related to the environmental disclosure practices.

\section{Literature review and hypothesis development}

Studies that have considered various firm characteristics as determinants of environmental disclosures abound in literature (see Fifka 2012; 2013). These characteristics include, but not limited to firm size, profitability, industry type, leverage etc. Similarly, this study determines the influence of corporate characteristics of firm size, profitability, auditor type, age and firm's foreign association on environmental disclosures, with an emphasis on industry sensitivity.

\section{Firm size}

Several empirical studies have found significant evidence that there is a positive relationship between company size and the level of social and environmental disclosure
(Brammer and Pavelin 2006; Cowen et al. 1987; Gray et al. 1995; Hackston and Milne 1996; Patten 2002, Patten 1992; Zeng et al. 2012). These studies argued that bigger firms are visible and exposed because of their size and image. Larger firms are, therefore, more willing to disclose environmental information to please their enormous stakeholders. Moreover, they are likely to seek capital externally and so disclose environmental information to alter societal perception. Again bigger firms are more prone to disclose environmental information than smaller firms to avoid punitive measures from regulators and reduce risk of regulation (Burgwal and Vieira 2014). Brammer and Pavelin (2008) study quality of voluntary disclosures in UK's industrial sector and analysed the determinants of disclosure. They find that bigger firms and nature of activities influence quality of disclosures.

Previous literature has attempted to explain why firm size is directly related to environmental disclosure. The first justification discusses cost of producing environmental information. It is argued that the cost of reporting environmental information is high, such that small firms may not be able to afford them from their limited resource (da Silva Monteiro and Aibar-Guzmán 2010). Therefore, larger companies might have sufficient resources to afford the cost of reporting information for the users of their annual reports. Secondly, agency cost is higher for large firms not to report on their environmental activities because their shareholders are widespread (Watts and Zimmerman 1983; Christ and Burritt 2013; Zeng et al. 2012). Thus, disclosing more information reduces the potential agency cost. Thirdly, extant literature suggest that larger companies tend to disclose more environmental information than smaller companies in their annual reports due to their competitive cost advantage (Lang and Lundholm 1993; Lobo and Zhou 2001; Kolk 2003). The size of the firm is operationalized using a number of measures, such as, sales, total assets and number of employees. This study adopts the natural logarithm of total assets as the proxy variable. The study therefore posits that:

\section{$H_{1}$ : Larger firms disclose more environmental information.}

\section{Profitability}

The relationship between profitability and environmental disclosure has produced mixed results. Whereas some of the studies conclude that there is a positive relationship between profitability and environmental disclosure (Al-Tuwaijri et al. 2004; Clarkson et al. 2011; Ingram 1978; Neu et al. 1998), other studies have failed to find a significant relationship between these two variables (Brammer and Pavelin 2006, 2008; Cowen et al. 1987; Freedman and Jaggi 1982; Hackston and Milne 1996; Patten 1991; da Silva Monteiro and Aibar-Guzmán 2010; 
Zeng et al. 2012). For example, Al-Tuwaijri et al. (2004) and Clarkson et al. (2011) indicate that profitability is significant and positively related to environmental disclosure. When profitability is high and a firm achieves a high margin of profit, the managerial groups are motivated to disclose more information in order to show off good reputation to the consumers, shareholders, investors and other stakeholders (Ullmann 1985). Indeed, firms would normally only engage in voluntary disclosures when they have made some economic gains. This is because disclosing environmental information entails cost, which firms will only bear when there is sufficient profit beyond fulfilling shareholders' obligation (Brammer and Pavelin 2006).

However, other studies report that a significant relationship between a company's profitability and its level of environmental disclosure does not exist (Choi 1999; Cowen et al. 1987; Hackston and Milne 1996; PradoLorenzo et al. 2009; Stanny and Ely 2008). This strand of literature argues that firms with low level of profitability tend to justify such unimpressive corporate performance through reporting their environmental activities. As these activities have cost implications, reporting them provides a justification for the lower level of reported profits. The effect of profit on environmental disclosures has therefore, been inconsistent in literature. However, following the argument of Cowen et al. (1987) and similar supporting studies, this study suggests that:

\section{$\mathrm{H}_{2}$ : Profitability of companies will not influence environmental disclosures.}

\section{Industry type}

Industry type refers to environmentally sensitive versus non-sensitive industries. Where environmentally sensitive industries refer to industries whose activities affect the environment directly. Mahmood (1999) suggests that disclosure levels reflect the type of industry, whilst Reverte (2009, p. 355) cite "mining, oil, and chemical industries as emphasising information regarding environmental, health, and safety issues" as opposed to finance and insurance companies. This makes such companies more environmentally sensitive. These disclosures are more aligned to companies whose activities affect the environment significantly (Brammer and Pavelin 2006, Brammer and Pavelin 2008; Campbell et al. 2003; Cho and Patten 2007; Deegan and Gordon 1996; Hackston and Milne 1996; Roberts 1992; Zeng et al. 2012). First of all, firms in sensitive industries comply with strict environmental regulations due to the emission effect of their activities and therefore should disclose their environmental concerns, otherwise stakeholders and especially investors may assume the worst
(Cormier and Magnan 2003; Clarkson et al. 2008; Cho and Patten 2007; Hackston and Milne 1996; da Silva Monteiro and Aibar-Guzmán 2010).

Moreover, environmentally sensitive industries face greater societal pressure because they are more likely to be associated with visible environmental concerns, like pollution and risk of environmental disasters (Brammer and Pavelin 2006; da Silva Monteiro and Aibar-Guzmán 2010). If these firms, therefore, fail to disclose their environmental performance, environmental pressure groups, NGO's, government and the general public may mount pressure on them, because they may be perceived as defying the social contract. Cowen et al. (1987) posit that industries that are consumer-oriented tend to disclose more as a public relation tool, while Patten (1991), Roberts (1992), and Cooke (1992) suggest that industries that tend to affect the environment most are afraid of reactions from the community and pressure groups and hence are likely to disclose more. Studies have associated a positive association between environmentally sensitive industries and environmental disclosures (Frost and Wilmshurst 2000; Joshi and Al-Modhahki 2003; Brammer and Pavelin 2006; Brammer and Pavelin 2008; Liu and Anbumozhi 2009. Cooke (1992) studied manufacturing and non-manufacturing firms in Japan, concluding that manufacturing firms disclose more environmental information. Similarly, this study posits that:

\section{$\mathrm{H}_{3}$ : Firms in the environmentally-sensitive industry provide more environmental disclosures than environmentally non-sensitive companies.}

\section{Auditor type}

Auditors endorse contents of annual reports. Though the provision of environmental information is voluntary, auditors have a responsibility to ensure any financial or nonfinancial information provided in the annual reports fairly represents what it purports to be. Society reposes confidence and trust in the 'big four' accounting firms. Larger firms tend to appoint one of the big four accounting firms to gain international acceptance and recognition. And since the 'big 4' (Pricewaterhouse Coopers(PWC), Klynveld Peat Marwick Goerdeler(KPMG), Deloitte \& Touche, Ernst \& Young) are interested in protecting their integrity and reputation, they may associate with companies who disclose environmental information (Alsaeed 2006). Thus, where financial statements are audited by them, it suggests an audit of even the voluntary disclosures. Thus companies may employ the big four to alter perception about their corporate disclosure behaviour and enhance their legitimacy. The issue of auditor type and its association with disclosures is uncertain in literature. Inchausti (1997), Ahmad et al. (2003) and Choi (1999) find 
a positive association between disclosures and auditor type. However, Hossain et al. (1995) found no support in their study of New Zealand companies. Similarly, Alsaeed (2006) also found no support for auditor type and disclosure. This study suggests that:

\section{$H_{4}$ : The type of auditors appointed by shareholders for a firm will affect disclosure of environmental information.}

\section{Foreign association}

Environmental disclosures are used as a tool for influencing perception and actions of stakeholders (Brammer and Pavelin 2004). Companies in Ghana may have foreign linkages through shareholding. These companies may be subsidiaries of bigger companies or an extension of their mother companies. They are therefore obliged to disclose environmental information because of their association with their foreign counterpart who may have already adopted these practices (DiMaggio and Powell 1983).Cormier et al. (2005, p.13) refer to it as imitation and explains it as "the tendency for firms that share similar structures to converge and adopt similar social structures" and this is more applicable to firms that have foreign parents. Thus, managerial behaviour is altered to adopt these practices through pressure and in the process legitimize their company's existence. The influence of foreign ownership structure on corporate disclosures have been mixed in literature (Brammer and Pavelin 2004; Ducassy and Montandrau 2015). Based on these insights, this study posits that;

\section{$H_{5}$ : foreign associated companies will disclose more environmental information}

\section{Age}

Older firms are more likely to engage in environmental performance to influence perception about their business and to legitimize their existence. Older firms are more likely to be bigger firms and may be willing to provide information to influence their continuous existence. Older firms may be abreast with current trends in their industry and are more apt at performing on new policies to sustain their business. Aerts et al. (2006) and Cochran and Wood (1984) study age with mixed results. Therefore this study posits that;

\section{$H_{6}:$ Older firms will disclose environmental information}

\section{Methodology}

\section{Sample}

The sample for the study was drawn from the Ghana Stock Exchange (GSE). Data was gathered for a 10-year period from 2003 to 2012. Thus the study adopts a longitudinal approach to examine trends in environmental disclosure practices of listed firms in Ghana. Although the GSE had a total of 34 companies listed as at December 2012, only 17 companies whose annual reports were readily available and accessible for the entire 10 -year period were included in the study analysis. To determine the industry sensitivity of the selected companies, the nature of their activities was considered from their company profile on the GSE website (www.gse.com.gh). Twelve (12) companies out of the sample were classified as environmentally sensitive because they pose a greater risk to the environment by the nature of their activities while the other five (5) companies were classified as non-sensitive firms (see Appendix 1 for the list of firms and industry classifications). The 12 environmentally sensitive companies belong to manufacturing, oil and gas, paper convertor and beverage industries. The non-sensitive companies include banks and insurance firms. Their corporate annual reports were obtained from corporate websites and the GSE. These were scanned and converted into word document to aid in the word search.

The GRI 3 disclosure checklist which gives a total of 13 environmental information indicator words was adopted. To determine the level of disclosure of the sampled firms, the content analysis technique was employed. Since the objective of the study is to determine the areas of environmental disclosure focus, the study uses word count rather than sentence count (Milne and Adler 1999). Word count has been used in prior disclosure studies (Campbell 2003; Campbell 2004; Deegan and Gordon 1996; Deegan et al. 2002; Gao et al. 2005). Although using word count does not consider the meaning of the word and the context of usage, it has been found to be useful for analysing text (Krippendorf 1980). Therefore, the content of each annual report was searched using the GRI indicator words as a measure. The total hit of each word was tabulated.

\section{Environmental disclosure scores}

A word count of environmental related words was collated based on the GRI checklist for each firm in the sample. The 13 environmental-related words highlighted by GRI are material, energy, water, biodiversity, emissions, effluent, waste, product, services, compliance, transport, supplier environmental assessment and environmental grievance mechanism. The term 'energy' was however replaced with 'electricity' as it is the common name within the Ghanaian context. The total word count for each environmental-related word is added up to represent the total environmental disclosure score which constitute the dependent variable for the study. 


\section{The independent variables}

The study considers six explanatory variables that may influence environmental disclosure i.e. firm size, profitability, auditor type, industry type, foreign association and age of the firm. Firm size is measured as the natural logarithm of total assets, while profitability is measured as return on assets based on operating profit. Auditor type is a dummy variable of zero (0) and one (1) for local audit firms and the 'big four' public accounting firms operating in Ghana respectively. Foreign associated firms are captured as one (1), while non-associated firms are captured as zero (0). Data for all these variables were obtained from the annual reports. Age of the company in any particular year is the number of years a company has been in existence from inception. Date of inception was sourced from the GSE website as a basis for determining years of existence. For industry type, the firms are grouped according to the nature of their activities. Their core business operation is obtained from the GSE company profile, enabling companies to be grouped into either environmentally sensitive or non-sensitive. Prior studies (Patten 1991; Roberts 1992; Clarkson et al. 2008) adopted this categorisation. Based on this categorisation, a total of 12 companies in the sample are considered environmentally sensitive with 5 being non-sensitive. A dummy variable of zero (0) is assigned to companies considered non-sensitive and one (1) assigned to environmentally sensitive firms.

\section{Estimation technique}

To assess empirically the influence of the above factors on the amount of disclosure by firms, the study utilizes the following basic formulation:

$$
\begin{aligned}
\text { EnvDisc }_{i t}= & \beta_{0}+\beta_{1} \text { size }_{i t}+\beta_{2} \text { profit }_{i t}+\beta_{3} \text { auditor }_{i t} \\
& +\beta_{4} \text { industry }_{i t}+\beta_{5} \text { foreignassoc }_{i t} \\
& +\beta_{6} \text { age }_{i t}+\varepsilon_{i t}
\end{aligned}
$$

Based on the above econometric model, the data was analyzed using the random effect panel regression approach with a correction for the heteroscedasticity of the standard error. The next section presents results from descriptive analysis followed by the empirical regression results and discussions.

\section{Results}

\section{Descriptive statistics}

Table 1 shows the descriptive statistics of the dependent and independent variables. It can be seen that the minimum amount of environmental disclosures in the annual report of the sampled companies is 0 with a maximum of 115 words. This shows a wide variability in environmental disclosures. This suggests
Table 1 Descriptive statistics

\begin{tabular}{llllll}
\hline Variable & Obs. & Mean & Std. Dev. & Min. & Max. \\
\hline EnvDisc & 170 & 39.4529 & 25.5903 & 0.0000 & 115.0000 \\
profit & 168 & 0.0695 & 0.1193 & -0.2481 & 0.4216 \\
size & 167 & 17.8098 & 1.9929 & 12.6960 & 21.8125 \\
age & 170 & 41.5588 & 17.3191 & 6.0000 & 88.0000 \\
foreignassoc & 170 & 0.4706 & 0.5006 & 0.0000 & 1.0000 \\
auditor & 170 & 0.8000 & 0.4012 & 0.0000 & 1.0000 \\
industry & 170 & 0.7059 & 0.4570 & 0.0000 & 1.0000 \\
\hline
\end{tabular}

Note: EnvDisc is Environmental Disclosures; profit is profitability; size represents firm size; age represents age of company; foreignassoc represents foreign association; auditor represents auditor type; industry represents industry type

that listed companies in Ghana are disclosing some amount of environmental-related information espoused by GRI, though this seems to be low. The size of the companies also shows wide variations from 12.69 to 21.8 .

With reference to the concentration of environmental disclosures, the study finds that sensitive companies are disclosing more product related information. Disclosure of this information had the highest count of 1267 words. This was followed by services (954); materials (506); compliance (462) and energy (393). The lowest disclosures were biodiversity (5) and emissions (8). With the non-sensitive companies, services had 1377 count, followed by product disclosures, 600 and compliance (488). As expected, there were no disclosures by the nonsensitive companies on biodiversity, emissions and effluent over the 10 -year period. This is basically because their activities do not affect the environment directly. This is depicted in Fig. 1. A T-test was run to determine if the means of the sample (sensitive and non-sensitive companies) are equal. This test showed that there are significant differences in the disclosure means of sensitive and nonsensitive industries $(p$-value $=0.000)$.

\section{Correlation matrix}

To ascertain whether the independent variables were highly correlated with each other to establish the existence or otherwise of multicollinearity issues in the dataset, correlation analysis was done using the study variables. Table 2 presents the results of the pairwise correlation matrix for the variables included in the empirical analysis. As shown in Table 2, multicollinearity is generally not an issue given that the extent of correlation among the independent variables is very low. The values of the pairwise correlation matrix for the independent variables were all below the recommended threshold of 0.8 (Gujarati and Porter 2003). 


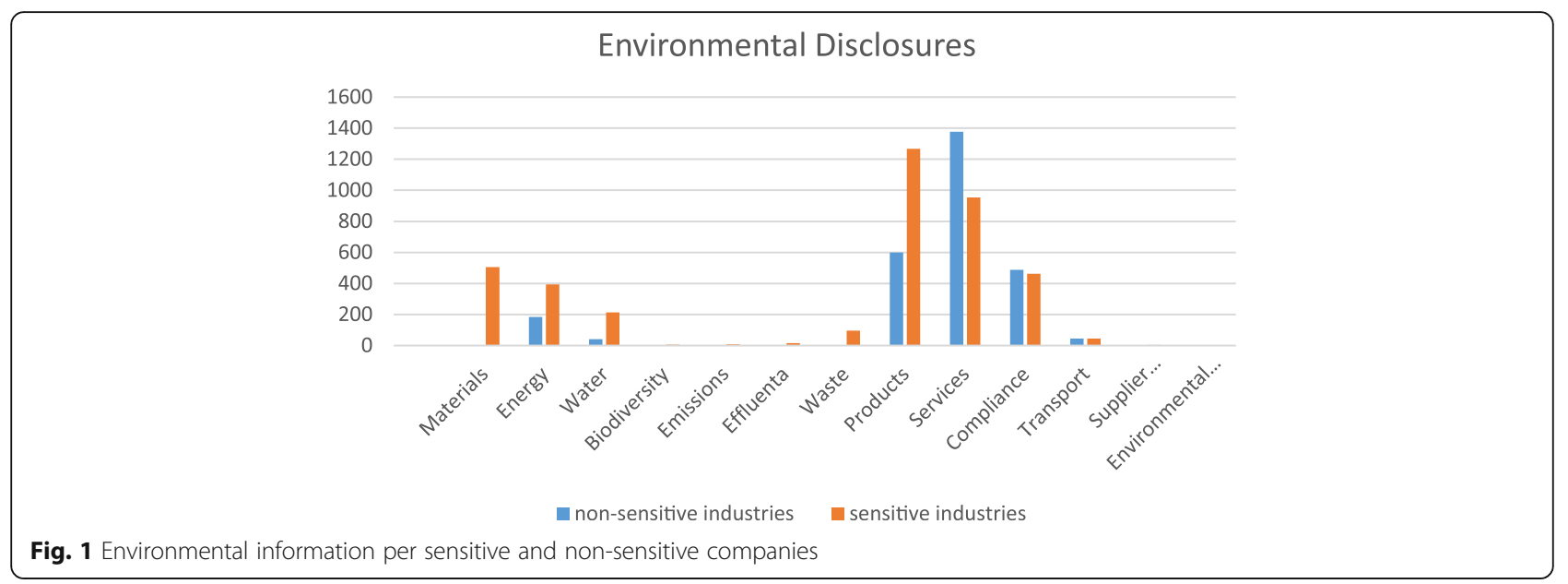

\section{Empirical results and discussions}

The traditional static models of fixed-effects and random effects were employed to analyse the data. While the Hausman test from the analysis favoured the fixed effect estimator $\left(\mathrm{Chi}^{2}\right.$ had a value of 27.49 and a Prob > $\mathrm{Chi}^{2}=0.000$ ), some of the dummy variables (foreign association and industry) were omitted from the model since they remain constant over the period. Consequently the random effect results were used in the final analysis to overcome the deficiencies associated with the fixed effect results similar to Wachira (2017). As Kohler and Kreuter (2009) suggest the random effect estimator handles better models that contain timeinvariant variables that are usually omitted by the fixed-effects model.

Table 2 Correlation matrix

\begin{tabular}{llllllll}
\hline Variable & EnvDisc & Industry & foreignassoc & auditor & size & profit & age \\
\hline EnvDisc & 1.0000 & & & & & & \\
industry & -0.3854 & 1.0000 & & & & \\
& $(0.0000)$ & & & & & \\
Foreignassoc & 0.2682 & -0.1583 & 1.0000 & & & \\
& $(0.0002)$ & $(0.0292)$ & & & & \\
auditor & 0.1996 & -0.0708 & 0.4848 & 1.0000 & & \\
& $(0.0140)$ & $(0.4030)$ & $(0.0000)$ & & & & \\
size & 0.6734 & -0.6015 & 0.3163 & 0.0969 & 1.0000 & & \\
& $(0.0000)$ & $(0.0000)$ & $(0.0000)$ & $(0.2131)$ & & & \\
profit & 0.0568 & 0.1201 & 0.3852 & 0.0050 & 0.0847 & 1.0000 & \\
& $(0.3025)$ & $(0.1678)$ & $(0.0000)$ & $(0.9671)$ & $(0.2766)$ & & \\
age & 0.0414 & 0.1784 & -0.1771 & 0.0505 & -0.1936 & -0.1923 & 1.0000 \\
& $(0.9055)$ & $(0.0135)$ & $(0.0111)$ & $(0.4270)$ & $(0.0122)$ & $(0.0031)$ & \\
\hline
\end{tabular}

Note: $P$-values are in parenthesis. EnvDisc is Environmental Disclosures; profit is profitability; size represents firm size; age represents age of company; foreignassoc represents foreign association; auditor represents auditor type; industry represents industry type
Results from the regression analysis are shown in Model 1 of Table 3. The results indicate that the model fit is good $\left(p=0.0000\right.$, Wald $\left.\mathrm{X}^{2}=132.92, \mathrm{R}^{2}=0.4872\right)$. From the results, the explanatory variables account for $48.72 \%$ of the variations in the environmental disclosures over the 10 -year period. The mean variance inflation factor (VIF) for this model is 5.44 suggesting that the coefficient estimates are not affected greatly by multicollinearity problems (see results in Appendix 2). Analysis of results in Model 1 suggests that industry type, firm size, age, and auditor type are positively associated with environmental disclosures in Ghana, whiles a negative relationship exists between firm performance and environmental disclosure. Also, a negative relationship exists between firms with foreign

Table 3 Regression results

\begin{tabular}{|c|c|c|c|c|c|c|}
\hline \multirow[t]{2}{*}{ Variable } & \multicolumn{3}{|c|}{ Model 1} & \multicolumn{3}{|c|}{ Model 2} \\
\hline & Coef. & Std. Err. & $P>|z|$ & Coef. & Std. Err. & $P>|z|$ \\
\hline Industry & 0.213 & 0.994 & 0.032 & 0.124 & 0.079 & 0.117 \\
\hline Foreignassoc & -0.106 & 0.089 & 0.905 & -0.025 & 0.071 & 0.732 \\
\hline Auditor & 0.076 & 0.767 & 0.319 & 0.151 & 0.073 & 0.040 \\
\hline Size & 0.167 & 0.017 & 0.000 & 0.126 & 0.016 & 0.000 \\
\hline Profit & -0.120 & 1.165 & 0.469 & -0.006 & 0.157 & 0.969 \\
\hline Age & 0.005 & 0.002 & 0.016 & 0.003 & 0.001 & 0.088 \\
\hline Cons. & -1.900 & 0.327 & 0.000 & -1.068 & 0.33 & 0.001 \\
\hline Observations & 167 & & & 167 & & \\
\hline Number of Firms & 17 & & & 17 & & \\
\hline R-Square & 0.4872 & & & 0.5149 & & \\
\hline
\end{tabular}

Note: EnvDisc is Environmental Disclosures; profit is profitability; size represents firm size; age represents age of company; foreignassoc represents foreign association; auditor represents auditor type; industry represents industry type 
association in terms of ownership and environmental information disclosure.

The results from the regression analysis in general are in line with theory and existing empirical evidence. As predicted in the study hypotheses, a positive and highly significant relationship (at 5\% significant level) was found between the industry sensitivity variable and environmental disclosure. This suggests that environmentally sensitive firms usually disclose more environmental-related information than firms whose activities do not have serious impact on the environment. This result is very much expected given that a number of legislations exist in most countries that regulate sensitive industries to disclose information on the impact of their activities on the environment. In Ghana, the Environmental Protection Agency (EPA) for instance, requires manufacturing and mining firms to report on their environmental-related activities periodically. These firms are rated with this information and their ratings are posted on the agency's website. Thus, in order to protect their reputation and also avoid costly sanctions and punitive measures from regulators, firms may disclose information relating to the environment. This finding supports earlier studies by Holder-Webb et al. (2009) and Zeng et al. (2012), who found a positive association between environment disclosures and industry type.

Also, the results show a positive and a highly significant relationship exists between firm size and environmental disclosure (at $1 \%$ significant level), an indication that larger firms disclose more environmental-related information than smaller firms. This finding suggests that firm size is an important determinant of environmental disclosure practice by Ghanaian firms and hence, supports the predicted hypothesis $\left(\mathrm{H}_{1}\right)$ of this study. Extant literature argues that larger firms are more willing to disclose environmental information because of their visibility and the desire to gain public confidence (Reverte 2009; Adams 2002; Cormier and Gordon 2001; Kamal and Deegan 2013). Moreover, such firms may want to attract external funding hence, their willingness to make environmental disclosures. As Watts and Zimmerman (1983) point out, larger firms are subject to pressure from stakeholders and the public. From the tenets of the legitimacy theory, firms would bow to such societal pressure and consequently disclose information on their environmental activities in an attempt to gain legitimacy. This finding is consistent with many empirical studies that associate the level of disclosure with firm size (Brammer and Pavelin 2006; Burgwal and Vieira 2014; Brammer and Pavelin 2008; Zeng et al. 2012).

In terms of the relationship between age and the level of disclosure, findings of this study demonstrate that age is a good predictor of firms' environmental disclosure practices in Ghana. As shown in Table 3, age had a positive coefficient and statistically significant relationship (at 5\% significant level) with environmental disclosure. This indicates that older firms tend to disclose more environmental information than relatively new firms. This is not surprising given that best practices of entities are usually developed over time, hence, with time older firms, cautious of their reputation, may engage in activities that position them as socially responsible entities. This finding confirms the hypothesis that the age of a firm is an important determinant of its environmental disclosure practice and also compares favourably with a number of existing studies (Prencipe 2004; Moore 2001; Cormier et al. 2005).

On the other hand, while the coefficient estimate for the auditor type variable suggests a positive relationship exist between firms environmental disclosure and the type of auditor they engage for external auditing purposes, this relationship was found not to be statistically significant $(p$-value $=0.319)$. Thus, environmental disclosure of firms is not so much dependent on whether a firm engages the service of a "big 4" accounting firm or a local auditing firm despite the fact that environmental disclosures may be reviewed by auditors as part of the financials. By implication, while the engagement of a very well established auditing firm is expected to effect a number of positive outcomes on a client (firm), especially in the area of disclosure, their presence do not really affect the environmental disclosure behaviour of firms. Earlier studies by Hossain et al. (1995) and Alsaeed (2006) similarly, find no support for the perceived relationship between the auditor type and environmental disclosure behaviour of firms.

In terms of the relationship between firm performance (profitability) and environmental disclosure, the regression result shows a negative and an insignificant relationship. Thus, in line with our predictions, no significant differences exist between profitable and unprofitable firms in terms of the level of environmental disclosure. Impliedly, while some studies argue that management of profitable firms are usually motivated to disclose more information in order to show off good reputation to their stakeholders, the findings of this study do not support such assertion and indeed a contrary position may exist in the Ghanaian context given the negative coefficient in the estimated results. Empirically, a number of studies have also found an insignificant relationship between various profitability measures and environmental disclosure (Brammer and Pavelin 2006, 2008; Cowen et al. 1987; Freedman and Jaggi 1982; Hackston and Milne 1996; Patten 1991; da 
Silva Monteiro and Aibar-Guzmán 2010; Zeng et al. 2012; Welbeck 2017).

Lastly, the results also show an inverse but insignificant relationship between the ownership type of firms and the level environmental disclosure. This means ownership type does not really affect environmental disclosure practices of Ghanaian listed firms. While this finding is supported in related literature (Momin and Hossain 2011; Momin and Parker 2013), it also demonstrates that disclosure of environmental information by listed firms in Ghana does not depend on their association with foreign firms.

To control for heteroscedasticity and autocorrelation, the model was clustered for standard errors and the results are shown in Model 2 of Table 3. Firm size remains positive and significant at $1 \%$; auditor type becomes positive and significant at $5 \%$; whiles age remains positive and significant, but at $10 \%$. Interestingly, industry sensitive companies remain positive but insignificant.

\section{Conclusion}

In a context where environmental disclosure is voluntary, the study determines which environmental information listed firms in Ghana are mostly focusing on over a 10-year period. The study also assesses whether the sensitivity of a company's industry influences its level of environmental disclosures. The study is underpinned by the legitimacy theory which postulates that firms disclose environmental information mainly to maintain the implicit social contract, enhance their continuous existence in the environment and prevent legitimacy crises.

Based on a content analysis, a word search of the environmental disclosure indicators from the GRI was conducted to ascertain the amount of environmental disclosures in corporate annual reports of listed firms in Ghana. A descriptive analysis of the environmental information of the firms indicates that listed firms in Ghana are disclosing some environmental information, though low. They are disclosing more product and service related information; with virtually non-existent information on biodiversity, emissions and effluent. Using the random effect regression model, the effect of profitability, firm size, auditor type, industry type, foreign association and age on firms' environmental disclosure was estimated.

The results of the study demonstrate that industry sensitivity, firm size and age are important predictors of firms' environmental disclosure practice. By implication, bigger firms, older firms and environmentally sensitive firms disclose more information on the environment than their counterparts. However, profitability, ownership type and auditor type do not affect the disclosure behaviour of listed firms in Ghana in any significant manner.

Whiles there is some environmental information, the focus and relevance of such information to stakeholders for decision-making on the environmental performance of firms remain an issue. With environmental regulations in place, it seems enforcement is lacking. Hence there is the need for continuous and stringent measures to compel firms, especially those in the environmentally sensitive industries to disclose other environmental issues. The role of the Environmental Protection Agency of Ghana is key. They should institute stringent measures and sanctions that will make the cost of non-performance and non-disclosure very high. Moreover, activist stakeholders - environmentalist, NGOs and communities where these firms reside could mount pressure on firms to disclose other environmental issues.

\section{Endnotes}

${ }^{1}$ Egypt is the only African country that ranked among the first 50 countries that performed better environmentally based on Yale University's publication of Environmental Performance Index of 178 countries in 2014.

\section{Appendix 1}

Table 4 Industry classification of firms in the sample

\begin{tabular}{lll}
\hline Firm name & Industry type & $\begin{array}{l}\text { Industry } \\
\text { classification }\end{array}$ \\
\hline Produce Buying Company & Agriculture/ Agro Processing & 1 \\
Cocoa Processing company & Agriculture/ Agro Processing & 1 \\
HFC BANK & Finance/Insurance & 0 \\
GCB Bank Ltd & Finance/Insurance & 0 \\
SG-SSB Bank Ltd & Finance/Insurance & 0 \\
Enterprise Insurance Group & Finance/Insurance & 0 \\
Stand Chartered Bank Ltd & Finance/Insurance & 0 \\
Unilever Gh. Ltd & Manufacturing/Trading & 1 \\
PZ Cussons & Manufacturing/Trading & 1 \\
Mechanical Lloyd & Manufacturing/Trading & 1 \\
Aluworks & Manufacturing/Trading & 1 \\
Pioneer Kitchenware & Manufacturing/Trading & 1 \\
TOTAL Ghana & Metals/ Oil & 1 \\
African Champion & Paper Converter/ IT & 1 \\
Samwoode & Paper Converter/ IT & 1 \\
Guiness Ghana & Pharmacy/ Beverages & 1 \\
Fan Milk & Pharmacy/ Beverages & 1 \\
\hline
\end{tabular}




\section{Appendix 2}

Table 5 Variance Inflation Factor (VIF)

\begin{tabular}{lll}
\hline Variable & VIF & 1 NIF \\
\hline Size & 10.11 & 0.0989 \\
Age & 7.27 & 0.1375 \\
Auditor & 6.73 & 0.1485 \\
Industry & 3.37 & 0.2970 \\
Foreignassoc & 3.36 & 0.2979 \\
Profit & 1.82 & 0.5497 \\
Mean VIF & 5.44 &
\end{tabular}

Note: Size represents firm size; age represents age of company; auditor represents auditor type; industry represents industry type; foreignassoc represents foreign association; profit is profitability

\section{Acknowledgements}

We thank the anonymous reviewers and the editor for their insightful comments which were useful in improving the quality of this paper.

\section{Funding}

Not applicable.

\section{Authors' contributions}

All authors contributed to the development of the manuscript and have read and approved the final manuscript.

\section{Competing interests}

The authors declare that they have no competing interests.

\section{Publisher's Note}

Springer Nature remains neutral with regard to jurisdictional claims in published maps and institutional affiliations.

\section{Received: 23 August 2017 Accepted: 8 December 2017} Published online: 22 December 2017

\section{References}

Adams, C. A. (2002). Internal organisational factors influencing corporate social and ethical reporting: Beyond current theorising. Accounting, Auditing and Accountability Journal, 15(2), 223-250.

Aerts, W., Cormier, D., \& Magnan, M. (2006). Intra-industry imitation in corporate environmental reporting: An international perspective. Journal of Accounting and Public Policy, 25(3), 299-331.

Ahmad, Z., Hassan, S., \& Mohammad, J. (2003). Determinants of environmental reporting in Malaysia. International Journal of Business Studies, 11(1), 69.

Alsaeed, K. (2006). The association between firm-specific characteristics and disclosure: the case of Saudi Arabia. Managerial Auditing Journal, 21(5), 476-496.

Al-Tuwaijri, S. A., Christensen, T. E., \& Hughes, K. E. (2004). The relations among environmental disclosure, environmental performance, and economic performance: A simultaneous equations approach. Accounting, Organizations and Society, 29(5), 447-471.

Brammer, S., \& Pavelin, S. (2004). Voluntary social disclosures by large UK companies. Business Ethics: A European Review, 13(2-3), 86-99.

Brammer, S., \& Pavelin, S. (2006). Voluntary environmental disclosures by large UK companies. Journal of Business Finance and Accounting, 33(7-8), 1168-1188.

Brammer, S., \& Pavelin, S. (2008). Factors influencing the quality of corporate environmental disclosure. Business Strategy and the Environment, 17(2), 120-136.

Branco, M. C., \& Rodrigues, L. L. (2006). Corporate social responsibility and resource-based perspectives. Journal of Business Ethics, 69(2), 111-132.

Brown, N., \& Deegan, C. (1998). The public disclosure of environmental performance information-A dual test of media agenda setting theory and legitimacy theory. Accounting and Business Research, 29(1), 21-41.
Burgwal, D. V. D., \& Vieira, R. J. O. (2014). Environmental disclosure determinants in Dutch listed companies. Revista Contabilidade and Finanças, 25(64), 60-78.

Campbell, D. (2003). Intra-and intersectoral effects in environmental disclosures: Evidence for legitimacy theory? Business Strategy and the Environment, 12(6), 357-371.

Campbell, D. (2004). A longitudinal and cross-sectional analysis of environmental disclosure in UK companies-A research note. The British Accounting Review, 36(1), 107-117

Campbell, D., Craven, B., \& Shrives, P. (2003). Voluntary social reporting in three FTSE sectors: A comment on perception and legitimacy. Accounting, Auditing and Accountability Journal, 16(4), 558-581.

Chandok, R. I. S., Chandok, R. I. S., Singh, S., \& Singh, S. (2017). Empirical study on determinants of environmental disclosure: Approach of selected conglomerates. Managerial Auditing Journal, 32(4/5), 332-355.

Chelli, M., Durocher, S., \& Richard, J. (2014). France's new economic regulations: Insights from institutional legitimacy theory. Accounting, Auditing and Accountability Journal, 27(2), 283-316.

Cho, C. H., \& Patten, D. M. (2007). The role of environmental disclosures as tools of legitimacy: A research note. Accounting, Organizations and Society, 32(7), 639-647.

Choi, J. S. (1999). An investigation of the initial voluntary environmental disclosures made in Korean semi-annual financial reports. Pacific Accounting Review, 11(1), 73-102.

Christ, K. L., \& Burritt, R. L. (2013). Environmental management accounting: The significance of contingent variables for adoption. Journal of Cleaner Production, 41, 163-173.

Clarkson, P. M., Li, Y., Richardson, G. D., \& Vasvari, F. P. (2008). Revisiting the relation between environmental performance and environmental disclosure: An empirical analysis. Accounting, Organizations and Society, 33(4), 303-327.

Clarkson, P. M., Li, Y., Richardson, G. D., \& Vasvari, F. P. (2011). Does it really pay to be green? Determinants and consequences of proactive environmental strategies. Journal of Accounting and Public Policy, 30(2), 122-144.

Cochran, P. L., \& Wood, R. A. (1984). Corporate social responsibility and financial performance. Academy of Management Journal, 27(1), 42-56.

Cooke, T. E. (1992). The impact of size, stock market listing and industry type on disclosure in the annual reports of Japanese listed corporations. Accounting and Business Research, 22(87), 229-237.

Cormier, D., \& Gordon, I. M. (2001). An examination of social and environmental reporting strategies. Accounting, Auditing \& Accountability Journal, 14(5), 587-617.

Cormier, D. \& Magnan, M. (2003). Environmental reporting management: A continental European perspective. Journal of Accounting and Public Policy, 22(1), 43-62.

Cormier, D., Magnan, M., \& Van Velthoven, B. (2005). Environmental disclosure quality in large German companies: Economic incentives, public pressures or institutional conditions? European Accounting Review, 14(1), 3-39.

Cowen, S. S., Ferreri, L. B., \& Parker, L. D. (1987). The impact of corporate characteristics on social responsibility disclosure: A typology and frequencybased analysis. Accounting, Organisations and Society, 12(2), 111-122.

Deegan, C. (2002). Introduction: The legitimising effect of social and environmental disclosures-a theoretical foundation. Accounting, Auditing \& Accountability Journal, 15(3), 282-311.

Deegan, C., \& Gordon, B. (1996). A study of the environmental disclosure practices of Australian corporations. Accounting and Business Research, 26(3), 189-199.

Deegan, C., Rankin, M., \& Tobin, J. (2002). An examination of the corporate social and environmental disclosures of BHP from 1983-1997: A test of legitimacy theory. Accounting, Auditing and Accountability Journal, 15(3), 312-343.

Díez-Martín, F., Prado-Roman, C., \& Blanco-González, A. (2013). Beyond legitimacy: Legitimacy types and organizational success. Management Decision, 51(10). 1954-1969.

DiMaggio, P., \& Powell, W. W. (1983). The iron cage revisited: Collective rationality and institutional isomorphism in organizational fields. American Sociological Review, 48(2), 147-160.

Dowling, J., \& Pfeffer, J. (1975). Organizational legitimacy: Social values and organizational behavior. Pacific Sociological Review, 122-136.

Ducassy, I., \& Montandrau, S. (2015). Corporate social performance, ownership structure and corporate governance in France. Research in International Business and Finance, 383-396.

Fifka, M. (2012). The development and state of research on social and environmental reporting in global comparison. Journal für Betriebswirtschaft, 62(1), 45-84.

Fifka, M. S. (2013). Corporate responsibility reporting and its determinants in comparative perspective-a review of the empirical literature and a meta-analysis. Business Strategy and the Environment, 22(1), 1-35.

Freedman, M., \& Jaggi, B. (1982). Pollution disclosures, pollution performance and economic performance. Omega, 10(2), 167-176. 
Frost, G. R., and Wilmshurst, T. D. (2000). The adoption of environment-related management accounting: an analysis of corporate environmental sensitivity. Accounting Forum, 24(4), 344-365.

Gao, S. S., Heravi, S., \& Xiao, J. Z. (2005). Determinants of corporate social and environmental reporting in Hong Kong: a research note. Accounting Forum, 29(2), 233-242.

Global Reporting Initiative. (2002). A historic collaborative achievement: Inauguration of the global reporting initiative. Amsterdam: Global Reporting Initiative [document on file with author].

Gray, R., Kouhy, R., \& Lavers, S. (1995). Corporate social and environmental reporting: A review of the literature and a longitudinal study of UK disclosure. Accounting, Auditing and Accountability Journal, 8(2), 47-77.

Gray, R., Javad, M., Power, D. M., \& Sinclair, C. D. (2001). Social and environmental disclosure and corporate characteristics: A research note and extension. Journal of Business Finance and Accounting, 28(3-4), 327-356.

Gujarati, D. N., \& Porter, D. C. (2003). Basic econometrics (4th ed.). New York: McGraw-Hill.

Hackston, D., \& Milne, M. J. (1996). Some determinants of social and environmental disclosures in New Zealand companies. Accounting, Auditing and Accountability Journal, 9(1), 77-108.

Holder-Webb, L., Cohen, J. R., Nath, L., \& Wood, D. (2009). The supply of corporate social responsibility disclosures among US firms. Journal of Business Ethics, 84(4), 497-527.

Hossain, M., Perera, M. H. B., \& Rahman, A. R. (1995). Voluntary disclosure in the annual reports of New Zealand companies. Journal of International Financial Management and Accounting, 6(1), 69-87.

Inchausti, B. G. (1997). The influence of company characteristics and accounting regulation on information disclosed by Spanish firms. The European Accounting Review, 6(1), 45-68.

Ingley, C. B. (2008). Company growth and board attitudes to corporate social responsibility. International Journal of Business Governance and Ethics, 4(1), 17-39.

Ingram, R. W. (1978). An investigation of the information content of (certain) social responsibility disclosures. Journal of Accounting Research, 16(2), 270285.

Jenkins, H., \& Yakovleva, N. (2006). Corporate social responsibility in the mining industry: Exploring trends in social and environmental disclosure. Journal of Cleaner Production, 14(3), 271-284.

Joshi, P. L., \& Al-Modhahki, J. (2003). Financial reporting on the internet: Empirical evidence from Bahrain and Kuwait. Asian Review of Accounting, 11(1), 88-101.

Kamal, Y., \& Deegan, C. (2013). Corporate social and environment-related governance disclosure practices in the textile and garment industry: Evidence from a developing country. Australian Accounting Review, 23(2), 117-134.

Kohler, U., \& Kreuter, F. (2009). Data analysis using Stata (2nd ed.). College Station: Stata Press.

Kolk, A. (2003). Trends in sustainability reporting by the fortune global 250. Business Strategy and the Environment, 12(5), 279-291.

Krippendorf, K. (1980). Content analysis: An introduction to its methodology. Beverly Hills: Sage Publications.

Lang, M., \& Lundholm, R. (1993). Cross-sectional determinants of analyst ratings of corporate disclosures. Journal of Accounting Research, 246-271.

Lindblom, C. K. (1994). The implications of organizational legitimacy for corporate social performance and disclosure. Critical Perspectives on Accounting, 120(3).

Liu, X., \& Anbumozhi, V. (2009). Determinant factors of corporate environmenta information disclosure: An empirical study of Chinese listed companies. Journal of Cleaner Production, 17(6), 593-600.

Lobo, G. J., \& Zhou, J. (2001). Disclosure quality and earnings management. Asia-Pacific Journal of Accounting and Economics, 8(1), 1-20.

Mahmood, A. (1999). The impact of market characteristics on the comprehensiveness of disclosure in financial reports: An empirical study. The Journal of Commercial Researches, 13(1), 47.

Milne, M. J., \& Adler, R. W. (1999). Exploring the reliability of social and environmental disclosures content analysis. Accounting, Auditing and Accountability Journal, 12(2), 237-256

Mitchell, C. G., \& Hill, T. R. (2010). An exploratory analysis of stakeholders' expectations and perceptions of corporate social and environmental reporting in South Africa. South African Journal of Accounting Research, 24(1), 49-78.

Mitchell, C. G., \& Quinn, N. W. (2005). Environmental reporting disclosure in South Africa: A comparative study of the expectations of selected groups of preparers and users. Meditari Accountancy Research, 13(2), 17-33.

Momin, M. A., \& Hossain, M. (2011). Corporate social responsibility (CSR) reporting by multinational corporations (MNCs) subsidiaries in an emerging country. Corporate Social Responsibility and Environmental Management, 35(7), 577-601.
Momin, M. A., \& Parker, L. D. (2013). Motivations for Corporate Social Responsibility Reporting by MNC subsidiaries in an emerging country: The case of Bangladesh. British Accounting Review, 45, 215-228.

Moore, G. (2001). Corporate social and financial performance: An investigation in the U.K. supermarket industry. Journal of Business Ethics, 34(3/4), 299-315.

Neu, D., Warsame, H., \& Pedwell, K. (1998). Managing public impressions: Environmental disclosures in annual reports. Accounting, Organizations and Society, 23(3), 265-282.

Nor, N. M., Bahari, N. A. S., Adnan, N. A., Kamal, S. M. Q. A. S., \& Ali, I. M. (2016). The effects of environmental disclosure on financial performance in Malaysia. Procedia Economics and Finance, 35, 117-126.

O'Donovan, G. (2002). Environmental disclosures in the annual report: Extending the applicability and predictive power of legitimacy theory. Accounting, Auditing and Accountability Journal, 15(3), 344-371.

Patten, D. M. (1991). Exposure, legitimacy, and social disclosure. Journal of Accounting and Public Policy, 10(4), 297-308.

Patten, D. M. (1992). Intra-industry environmental disclosures in response to the Alaskan oil spill: A note on legitimacy theory. Accounting, Organizations and Society, 17(5), 471-475.

Patten, D. M. (2002). The relation between environmental performance and environmental disclosure: A research note. Accounting, Organizations and Society, 27(8), 763-773.

Pereira Eugénio, T., Costa Lourenço, I., \& Morais, A. I. (2013). Sustainability strategies of the company TimorL: extending the applicability of legitimacy theory. Management of Environmental Quality: An International Journal, 24(5), 570-582.

Pfeffer, J., \& Salancik, G. R. (1978). The external control of organizations: A resource dependence approach. NY: Harper and Row Publishers.

Prado-Lorenzo, J. M., Gallego-Alvarez, I., \& Garcia-Sanchez, I. M. (2009). Stakeholder engagement and corporate social responsibility reporting: the ownership structure effect. Corporate Social Responsibility and Environmental Management, 16(2), 94-107.

Prencipe, A. (2004). Proprietary costs and determinants of voluntary segment disclosure: Evidence from Italian listed companies. European Accounting Review, 13(2), 319-340.

Reverte, C. (2009). Determinants of corporate social responsibility disclosure ratings by Spanish listed firms. Journal of Business Ethics, 88(2), 351-366.

Roberts, R. W. (1992). Determinants of corporate social responsibility disclosure: An application of stakeholder theory. Accounting, Organisations and Society, 17(August), 595-612.

Shocker, A. D., \& Sethi, S. P. (1974). An approach to incorporating action preferences in developing corporate action strategies. In The unstable ground: Corporate in a dynamic society, Melville, CA.

da Silva Monteiro, S. M., \& Aibar-Guzmán, B. (2010). Determinants of environmental disclosure in the annual reports of large companies operating in Portugal. Corporate Social Responsibility and Environmental Management, 17(4), 185-204.

Stanny, E., \& Ely, K. (2008). Corporate environmental disclosures about the effects of climate change. Corporate Social Responsibility and Environmental Management, 15(6), 338-348.

Sulaimana, M., Abdullahb, N., \& Fatimaa, A. H. (2014). Determinants of environmental reporting quality in Malaysia. International Journal of Economics, Management and Accounting, 22(1), 63.

Sumiani, Y., Haslinda, Y., \& Lehman, G. (2007). Environmental reporting in a developing country: A case study on status and implementation in Malaysia. Journal of Cleaner Production, 15(10), 895-901.

Suttipun, M. \& Stanton, P. (2012). Determinants of environmental disclosure in Thai corporate annual reports. International Journal of Accounting and Financial Reporting, 2(1), 99.

Tilling, M. V., \& Tilt, C. A. (2010). The edge of legitimacy: Voluntary social and environmental reporting in Rothmans' 1956-1999 annual reports. Accounting, Auditing and Accountability Journal, 23(1), 55-81.

Ullmann, A. A. (1985). Data in search of a theory: A critical examination of the relationships among social performance, social disclosure, and economic performance of U.S. firms. Academy of Management Review, 10(3), 540-557.

de Villiers, C. J. (2003). Why do south African companies not report more environmental information when managers are so positive about this kind of reporting? Meditari Accountancy Research, 11(1), 11-23.

de Villiers, C. J., \& Barnard, P. (2000). Environmental reporting in South Africa from 1994 to 1999: A research note. Meditari Accountancy Research, 8(1), 15-23.

de Villiers, C. J., \& Lubbe, D. S. (2001). Industry differences in respect of corporate environmental reporting in South Africa: A research note. Meditari Accountancy Research, 9(1), 81-91. 
Wachira, M. (2017). Determinants of corporate social disclosures in Kenya: A longitudinal study of firms listed on the Nairobi securities exchange. European Scientific Journal, 13(11), 1857-7881 (Print) e - ISSN 1857- 7431.

Watts, R. L., \& Zimmerman, J. L. (1983). Agency problems, auditing, and the theory of the firm: Some evidence. The Journal of Law and Economics, 26(3), 613-633.

Welbeck, E. E. (2017). The influence of institutional environment on corporate responsibility disclosures in Ghana. Meditari Accountancy Research, 25(2), 216-240.

Wilmshurst, T. D., \& Frost, G. R. (2000). Corporate environmental reporting: A test of legitimacy theory. Accounting, Auditing and Accountability Journal, 13(1), 10-26 www.gse.gh.com.

Zeng, S. X., Xu, X. D., Yin, H. T., \& Tam, C. M. (2012). Factors that drive Chinese listed companies in voluntary disclosure of environmental information. Journal of Business Ethics, 109(3), 309-321.

\section{Submit your manuscript to a SpringerOpen ${ }^{\odot}$ journal and benefit from:}

- Convenient online submission

- Rigorous peer review

- Open access: articles freely available online

- High visibility within the field

- Retaining the copyright to your article

Submit your next manuscript at $>$ springeropen.com 